\section{UK satellite firm acquired by European space giant}

Europe's largest space company, EADS Astrium, will acquire British microsatellite manufacturer Surrey Satellite Technology Limited (SSTL).

In a deal announced on 7 April, EADS will pay the University of Surrey between

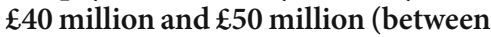
US\$80 million and $\$ 100$ million) for a majority stake in the company. Currently, the university holds an $\mathbf{8 0} \%$ share.

SSTL specializes in small satellites weighing between 10 and 100 kilograms. Its previous clients include nations such as Turkey and China, as well as the European Union, for whom it supplied the first satellite of Europe's Galileo Global Positioning System.

But the company has struggled to expand into larger markets such as the United States (see Nature 444, 804-805; 2006). The buyout will help growth, according to Martin Sweeting, SSTL's executive chairman. "This acquisition strengthens SSTL enormously while preserving our unique approach to space," he says.

\section{Brucellosis fears hamper Yellowstone bison plans}

A record number of bison foraging outside Yellowstone National Park have been captured and killed this winter as part of a US plan to try to keep the animals from spreading the disease brucellosis to livestock. The bacterium Brucella abortus can cause spontaneous abortion in cattle.

Although the effort has successfully prevented bison-cattle contact, last week the Government Accountability Office reported that the plan has fallen behind in its other goal of allowing more bison to range outside the park. Since 2000, federal and state agencies have struggled to secure additional land for grazing and find a way to deliver the RB51 brucellosis vaccine to bison calves and yearlings.

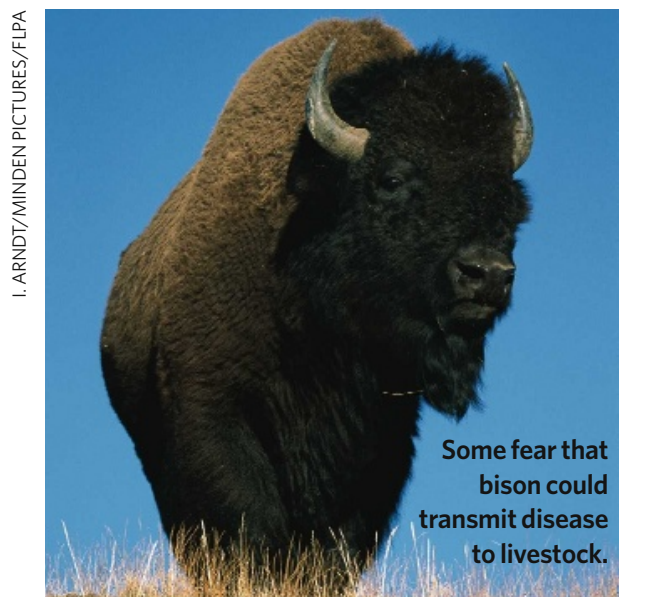

\title{
An insight into amber
}

Suspended deep inside opaque pieces of amber, this spider and conifer branch have remained hidden for around 100 million years.

Now they, and some 350 other organisms including wasps, flies and ants, can be viewed thanks to a technique that can see through the fossilized tree resin that holds them.

French palaeontologists at

the University of Rennes, in collaboration with the European

Synchrotron Radiation Facility

in Grenoble, used a synchrotron

$\mathrm{X}$-ray imaging technique called propagation-

phase contrast microradiography to make the organisms visible. They examined around two

kilograms of opaque amber from mid-Cretaceous sites

in southwestern France and produced a series of spectacular

three-dimensional images (see www.esrf.eu/news/general/amber).

An aerial survey last month revealed that the Yellowstone bison population fell from 4,700 last summer to roughly 3,000 .

\section{Tanzania takes steps to save ancient human prints}

The world's oldest human footprints are to have a museum built around them in a bid to protect them. The 3.7-million-year-old tracks in an ash bed in Laetoli, Tanzania, are threatened by erosion.

A 15-member government committee approved the 5-year plan, which calls for US $\$ 25$ million to be raised for the facility.

Archaeologist Paul Msemwa, director of the National Museum in Dar es Salaam who chairs the committee, says that the panel will decide in the next month on the specific remedial measures to protect the footprints. A protective layer placed over the prints is deteriorating (see Nature 451, 118; 2008).

Environmental assessments and work are already under way to carve a road into Ngorongoro National Park past the Laetoli site, to provide electricity and a temporary visitor centre, officials say.

\section{Pfizer fails to gain access to peer-review files}

A federal magistrate in Massachusetts last week ruled that The New England Journal of Medicine (NEJM) does not have to comply with a subpoena issued by Pfizer forcing the journal to provide confidential peerreview documents related to the painkillers Celebrex (celecoxib) and Bextra (valdecoxib).

The drug firm had tried to compel the NEJM to hand over peer reviews and internal editorial discussions for 11 papers on the painkillers. It argued that these would help it defend the arthritis drugs in lawsuits alleging that they caused heart attacks and strokes (see Nature 452, 6-7; 2008).

In his 12-page opinion, Leo Sorokin wrote that the material Pfizer sought seemed relevant on first examination, but that "NEJM's interest in maintaining the confidentiality of the peer-review process is a very significant one ... and tip [s] the scales in favor of the NEJM."

The judgement comes three weeks after an Illinois judge ruled against Pfizer after it issued almost identical subpoenas to The Journal of the American Medical Association and Archives of Internal Medicine.

\section{Environment agency reopens doors to libraries}

The US Environmental Protection Agency (EPA) last month announced that by 30 September it will have reopened five agency libraries that it recently closed in Chicago, Dallas, Kansas City (Missouri) and Washington DC.

Critics had seen the closures as a move to control information at the agency, and the resulting outcry triggered Congress to allocate \$1 million for fiscal year 2008 to reopen the libraries.

The EPA has described the closures as an efficiency move, and said all along that it intends to digitize and make available online the material that was formerly available in hard copy at its libraries. A committee of the Library of Congress is consulting with the EPA on its longer-term library plans.

\section{Correction}

Our News story 'Drug markers questioned' (Nature 452, 510-511; 2008) incorrectly stated that Gleevec (imatinib) has been approved to treat breast cancer. Gleevec is used to treat chronic myeloid leukaemia. 